\title{
The Influence of the NHT Assisted Media Model and Learning Motivation on Learning Outcomes of Citizenship Education
}

\author{
Fauziah Nasution, ${ }^{1}$, Deny Setiawan ${ }^{2}$, Wildansyah Lubis ${ }^{2}$ \\ ${ }^{1}$ Universitas Negeri Medan, Medan, Indonesia \\ 2Universitas Negeri Medan, Medan, Indonesia \\ Email: fauziahnst429@gmail.com
}

\begin{abstract}
The aim of this research is to know the influence of NHT assisted media model and learning motivation on learning outcomes of citizenship education. This research will be implemented in $5^{\text {th }}$ grade of Primary School at SD IT Tahfizhil Quran YIC SU, which is located at Jalan Haji Hospital. This school has an " $A$ " accreditation. The research activities were carried out in the first semester of the 2018-2019 Academic Year, setting the research schedule according to the schedule set by the school principal. The subject matter selected in this study is "Diversity" which is the material in the class IV syllabus that is being studied in the semester.

Keywords: teaching materials; short story text; writing
\end{abstract}

\section{Introduction}

In general the learning atmosphere developed by the teacher runs unilaterally because it uses conventional learning and tends to be monotonous, in the process the teacher explains the material with a lecture, students listen then notes what is considered important. The main source in this learning is the teacher's explanation, students who are passive only listen to the description of the material and receive the full knowledge or information from the teacher. This results in the information obtained is less so attached to and imprint on students. With this step students also quickly get bored, if a situation like this continues it will certainly be bad for students.

One learning model that can help achieve student learning outcomes effectively is the interactive learning model Type Number Head Together. The Number Head Together learning model is part of an interactive learning model that emphasizes specific structures designed to influence student interaction patterns in searching, processing and reporting information from various sources which are finally presented in front of the class so that they can train students to share information, listen carefully and speak with calculation so that students are more productive in learning. By using the interactive learning model Type Number Head Together there is a tendency for teachers to train students in working together to find their own concepts about learning. The Number Head Together model also fosters student activity to learn PPKn so that students do not feel bored in the classroom.

From the results of previous studies on Agni Era Hafsari research (2017: 1-9) the influence of NHT type interactive learning models assisted by Audiovisual media has an impact on classroom situations and students. Changes in student conditions include active students, the courage to make presentations, and the learning atmosphere becomes fun. This is evidenced by the results on the pre-cycle average of 62.25 and completeness of $20 \%$, after learning by using NHT learning models assisted by audiovisual media there was a significant increase of up to $100 \%$. 


\section{Research Methods}

This research will be implemented in $5^{\text {th }}$ grade of Primary School at SD IT Tahfizhil Quran YIC SU, which is located at Jalan Haji Hospital. This school has an "A" accreditation. The research activities were carried out in the first semester of the 2018-2019 Academic Year, setting the research schedule according to the schedule set by the school principal. The subject matter selected in this study is "Diversity" which is the material in the class IV syllabus that is being studied in the semester.

\section{Discussion}

Based on the data obtained from the results of high motivation posttest students who were taught with the Audiovisual Media Assisted NHT Learning model in appendix 6 and the frequency distribution data can be described as follows: the calculated mean value $(\mathrm{X})$ of 23.23; Variance $=12.37 ;$ Standard Deviation $(S D)=3.52 ;$ maximum value $=28 ;$ minimum value $=18$, with a range of values (Range) $=10$. The meaning of the variance results above is the high motivation of students taught with the NHT Assisted Audiovisual Media Learning model that has a variety of values or different between students with one another, because we can see that the value of variance exceeds the highest value from the data above. Quantitatively it can be seen in the following table:

Table 1. Frequency Distribution of Students' High Motivation Data Taught by NHT Learning Models Assisted by Audiovisual Media $\left(\mathrm{A}_{1} \mathrm{~B}_{1}\right)$

\begin{tabular}{|c|c|c|c|}
\hline Class & Class Interval & Frequency & Frequency Cumulative(\%) \\
\hline 1 & $18-19$ & 4 & 18,18 \\
\hline 2 & $20-21$ & 5 & 22,73 \\
\hline 3 & $22-23$ & 2 & 9,09 \\
\hline 4 & $24-25$ & 3 & 13,64 \\
\hline 5 & $26-27$ & 5 & 22,73 \\
\hline 6 & $28-29$ & 3 & 13,64 \\
\hline \hline Total & & $\mathbf{2 2}$ & $\mathbf{1 0 0}$ \\
\hline
\end{tabular}

Based on these values, a group data histogram can be formed as follows:

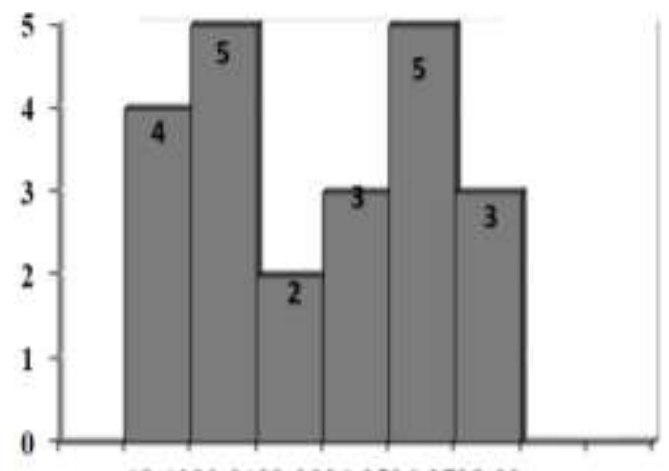

18-1920-2122-2324-2526-2728-29

Figure 1. Histogram High Student Motivation Taught by Learning Models Assisted by Audiovisual Media (A1B1) 
While the category of assessment of high motivation data of students taught with the NHT Learning Model Assisted Audiovisual Media can be seen in the following table:

Table 2. Categories of Student High Motivation Evaluation Categories Taught by the Audiovisual Media Assisted NHT Learning Model $\left(\mathrm{A}_{1} \mathrm{~B}_{2}\right)$

\begin{tabular}{|c|c|c|c|c|}
\hline No & Rating Interval & Total Students & Percentage & Assessment Category \\
\hline 1 & $0 \leq \mathrm{MT}<45$ & 0 & $0 \%$ & Very Less \\
\hline 2 & $45 \leq \mathrm{MT}<65$ & 4 & $18 \%$ & Less \\
\hline 3 & $65 \leq \mathrm{MT}<75$ & 6 & $27 \%$ & Enough \\
\hline 4 & $75 \leq \mathrm{MT}<90$ & 9 & $41 \%$ & Well \\
\hline 5 & $90 \leq \mathrm{MT} \leq 100$ & 3 & $14 \%$ & Very Well \\
\hline
\end{tabular}

Note: MT $=$ High Motivation

Table 3. Frequency Distribution of Students' High Motivation Data Taught by the NHT Learning Model Using Media Images $\left(\mathrm{A}_{2} \mathrm{~B}_{1}\right)$

\begin{tabular}{|c|c|c|c|}
\hline Class & Class Interval & Frequency & Frequency Cumulative (\%) \\
\hline 1 & $11-13$ & 3 & 13,64 \\
\hline 2 & $14-16$ & 4 & 18,18 \\
\hline 3 & $17-19$ & 5 & 22,73 \\
\hline 4 & $20-22$ & 4 & 18,18 \\
\hline 5 & $23-25$ & 5 & 22,73 \\
\hline 6 & $26-28$ & 1 & 4,55 \\
\hline \multicolumn{2}{|r|}{ Total } & 22 & 100 \\
\hline
\end{tabular}

Based on these values, a group data histogram can be formed as follows:

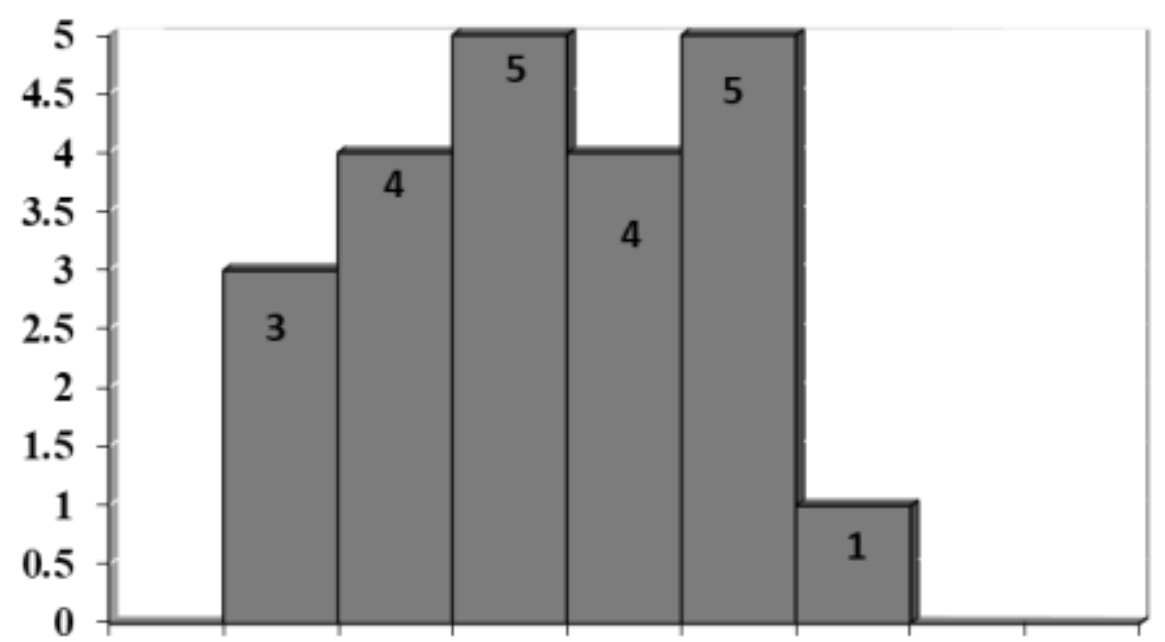

11_13 14-16 17-19 20-22 23-25 26-28

Figure 2. High Motivation Histogram for Students Taught by NHT Learning Model with Media Assistance $\left(\mathrm{A}_{2} \mathrm{~B}_{1}\right)$

Whereas the category of assessment of high motivation data of students taught with the NHT Learning model assisted with picture media can be seen in the following table: 
Table 4. Student High Motivation Assessment Categories Taught By Image Media Assisted NHT Learning Model $\left(\mathbf{A}_{2} \mathbf{B}_{1}\right)$

\begin{tabular}{|c|c|c|c|c|}
\hline No & Rating Interval & Total of Students & Percentage & Category Assessment \\
\hline 1 & $0 \leq \mathrm{MT}<45$ & 3 & $14 \%$ & Very Less \\
\hline 2 & $45 \leq \mathrm{MT}<65$ & 9 & $41 \%$ & Less \\
\hline 3 & $65 \leq \mathrm{MT}<75$ & 4 & $18 \%$ & Enough \\
\hline 4 & $75 \leq \mathrm{MT}<90$ & 6 & $27 \%$ & Well \\
\hline 5 & $90 \leq \mathrm{MT} \leq 100$ & 0 & $0 \%$ & Very Well \\
\hline & & 22 & $100 \%$ & \\
\hline
\end{tabular}

Note: MT = High Motivation

Tabel 5. Frequency Distribution of Motivation Data for Low Students Taught Using NHT Learning Models Assisted by Audiovisual Media $\left(\mathrm{A}_{1} \mathrm{~B}_{2}\right)$

\begin{tabular}{|c|c|c|c|}
\hline Class & Class Interval & Frequency & Frequency Cumulative (\%) \\
\hline 1 & $10-12$ & 3 & 13,64 \\
\hline 2 & $13-15$ & 5 & 22,73 \\
\hline 3 & $16-18$ & 5 & 22,73 \\
\hline 4 & $19-21$ & 4 & 18,18 \\
\hline 5 & $22-24$ & 5 & 22,73 \\
\hline Total & & $\mathbf{2 2}$ & $\mathbf{1 0 0}$ \\
\hline
\end{tabular}

Based on these values, a group data histogram can be formed as follows:



$10 \_12 \quad 13-15$ 16-18 19-21 22-24

Figure 3. Histogram Motivation of Low Students Taught Using NHT Learning Model Assisted by Audiovisual Media $\left(\mathrm{A}_{1} \mathrm{~B}_{2}\right)$

Whereas the category of assessment of low motivation data of students taught using the NHT learning model can be seen in the following Table: 
Table 6. The Low Student Motivation Assessment Category Taught Using the Audiovisual Media Assisted NHT Learning Model $\left(\mathrm{A}_{1} \mathrm{~B}_{2}\right)$

\begin{tabular}{|c|c|c|c|c|}
\hline No & Rating Interval & Total Students & Percentage & Assessment Category \\
\hline 1 & $0 \leq \mathrm{MR}<45$ & 5 & $23 \%$ & Very Less \\
\hline 2 & $45 \leq \mathrm{MR}<65$ & 9 & $41 \%$ & Less \\
\hline 3 & $65 \leq \mathrm{MR}<75$ & 4 & $18 \%$ & Enough \\
\hline 4 & $75 \leq \mathrm{MR}<90$ & 4 & $18 \%$ & Well \\
\hline 5 & $90 \leq \mathrm{MR} \leq 100$ & 0 & $0 \%$ & Very Well \\
\hline & & 22 & $100 \%$ & \\
\hline
\end{tabular}

Note: MR = Low Motivation

Table 7. Frequency Distribution of Motivation Data of Students Who Are Teased Using NHT Learning Using Image Media $\left(\mathrm{A}_{2} \mathrm{~B}_{2}\right)$

\begin{tabular}{|c|c|c|c|}
\hline Class & Class Interval & F & F0 \\
\hline 1 & $8-11$ & 4 & 18,18 \\
\hline 2 & $12-15$ & 6 & 27,27 \\
\hline 3 & $16-19$ & 4 & 18,18 \\
\hline 4 & $20-23$ & 4 & 18,18 \\
\hline 5 & $24-27$ & 4 & 18,18 \\
\hline \multicolumn{2}{|c|}{ Total } & $\mathbf{2 2}$ & $\mathbf{1 0 0}$ \\
\hline
\end{tabular}

Based on these values, a group data histogram can be formed as follows:

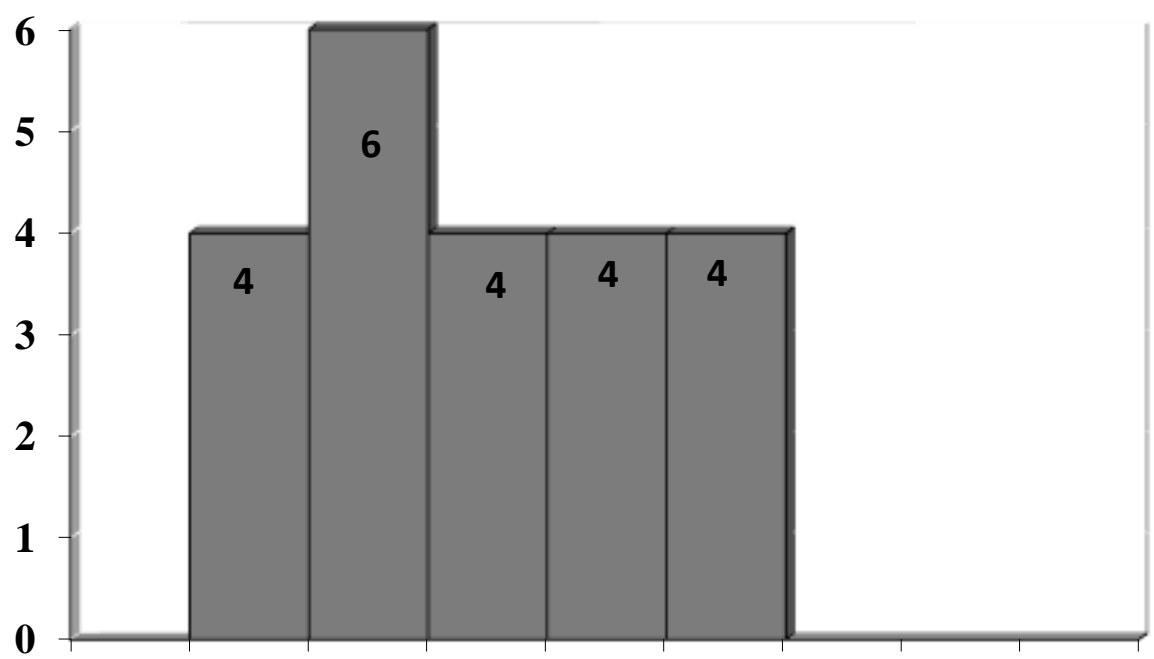

08_11 12_15 16-19 20-23 24-27

Figure 4. Histogram Motivation of Low Students Taught Using NHT Learning Aided by Image Media $\left(\mathrm{A}_{2} \mathrm{~B}_{2}\right)$

Whereas the category of assessment of low motivation data of students taught with NHT Learning assisted by media images can be seen in the following table: 
Table 8. Low Student Motivation Evaluation Category Taught by Image-Aided NHT Learning $\left(\mathrm{A}_{1} \mathrm{~B}_{1}\right)$

\begin{tabular}{|c|c|c|c|c|}
\hline No & Rating Interval & Total Students & Percentage & Assessment Category \\
\hline 1 & $0 \leq \mathrm{MR}<45$ & 6 & $27 \%$ & Very Less \\
\hline 2 & $45 \leq \mathrm{MR}<65$ & 8 & $36 \%$ & Less \\
\hline 3 & $65 \leq \mathrm{MR}<75$ & 3 & $14 \%$ & Enough \\
\hline 4 & $75 \leq \mathrm{MR}<90$ & 5 & $23 \%$ & Well \\
\hline 5 & $90 \leq \mathrm{MR} \leq 100$ & 0 & $0 \%$ & Very Well \\
\hline & & 22 & $100 \%$ & \\
\hline
\end{tabular}

Note: $\mathrm{MR}=$ Low Motivation

From the table above, the low motivation of students taught with NHT Learning assisted by the picture media shows that: the number of students who scored very poorly namely 6 people or $27 \%$, who had less categories of 8 people or $36 \%$, who had a category value enough as many as 3 people or by $14 \%$, which has a good category value of 5 people or $23 \%$, which has a very good category value ie no or as much as $0 \%$.

Table 9. Frequency Distribution of High and Low Motivation Data Taught by Using NHT Learning Models Assisted by Audiovisual Media $\left(A_{1}\right)$

\begin{tabular}{|c|c|c|c|}
\hline Class & Class Interval & Frequency & Frequency Cumulative (\%) \\
\hline 1 & $10-12$ & 3 & 6,82 \\
\hline 2 & $13-15$ & 5 & 11,36 \\
\hline 3 & $16-18$ & 7 & 15,91 \\
\hline 4 & $19-21$ & 11 & 25,00 \\
\hline 5 & $22-24$ & 8 & 18,18 \\
\hline 6 & $25-27$ & 7 & 15,91 \\
\hline 7 & $28-30$ & 3 & 6,82 \\
\hline & & 44 & 100 \\
\hline
\end{tabular}

Based on these values, a group data histogram can be formed as follows:

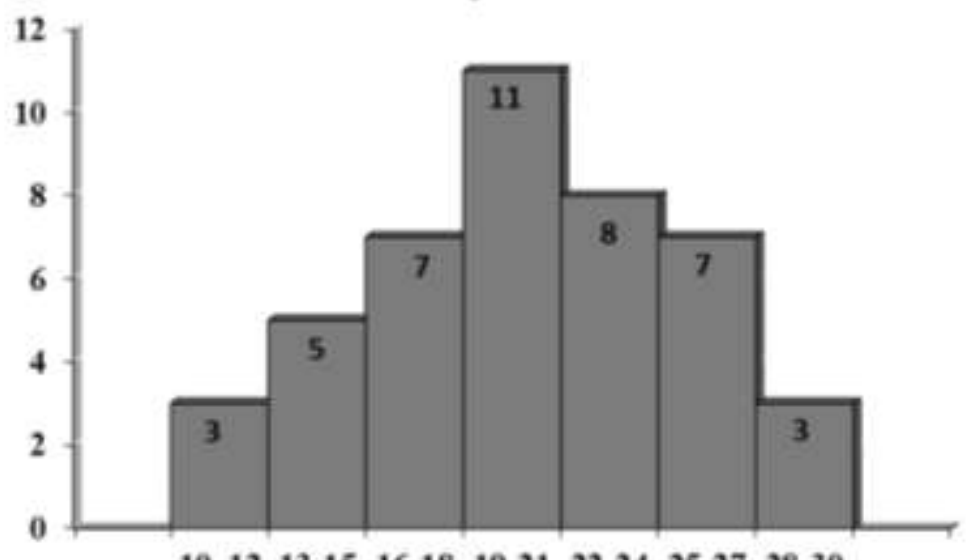

$\begin{array}{lllllllll}10 & 12 & 13-15 & 16-18 & 19-21 & 22-24 & 25-27 & 28-30\end{array}$

Figure 5. High and Low Motivation Histograms Taught by Using NHT Learning Models Assisted by Audiovisual Media $\left(\mathrm{A}_{1}\right)$

While the evaluation categories of high and low motivation posttest data taught using NHT learning models assisted by audiovisual media can be seen in the following table: 
Table 10. The High and Low Motivation Assessment Categories are Taught by Using NHT Learning Models Assisted by Audiovisual Media $\left(\mathrm{A}_{1}\right)$

\begin{tabular}{|c|c|c|c|c|}
\hline No & Rating Interval & Total of Students & Percentage & Assessment Category \\
\hline 1 & $0 \leq$ MTMR $<45$ & 5 & $11 \%$ & Very Less \\
\hline 2 & $45 \leq$ MTMR $<65$ & 13 & $30 \%$ & Less \\
\hline 3 & $65 \leq$ MTMR $<75$ & 10 & $23 \%$ & Enough \\
\hline 4 & $75 \leq$ MTMR $<90$ & 13 & $30 \%$ & Well \\
\hline 5 & $90 \leq$ MTMR $\leq 100$ & 3 & $7 \%$ & Very Well \\
\hline & & 44 & $100 \%$ & \\
\hline
\end{tabular}

Note: MTMR = High Motivation Low Motivation

From the table above, high and low motivation taught using the NHT learning model assisted by audiovisual media shows that: the number of students who score very less As many as 5 people or $11 \%$, who have less categories of 13 people or as much as $30 \%$, who have grades 10 categories are enough or as much as $23 \%$, which has a good category value of 13 people or $30 \%$, which has a very good category value of 3 or $7 \%$.

Table 11. The High And Low Motivation Data Frequency Distribution Taught Using The Image Media Assisted Learning Model $\left(\mathrm{A}_{2}\right)$

\begin{tabular}{|c|c|c|c|}
\hline Class & Class Interval & Frequency & Cumulative Frequency (\%) \\
\hline 1 & $8-10$ & 2 & 4,55 \\
\hline 2 & $11-13$ & 7 & 15,91 \\
\hline 3 & $14-16$ & 9 & 20,45 \\
\hline 4 & $17-19$ & 8 & 18,18 \\
\hline 5 & $20-22$ & 7 & 15,91 \\
\hline 6 & $23-25$ & 10 & 22,73 \\
\hline 7 & $26-28$ & 1 & 2,27 \\
\hline \hline \multicolumn{2}{r|}{ Total } & 44 & $\mathbf{1 0 0}$ \\
\hline
\end{tabular}

Based on these values, a group data histogram can be formed as follows:

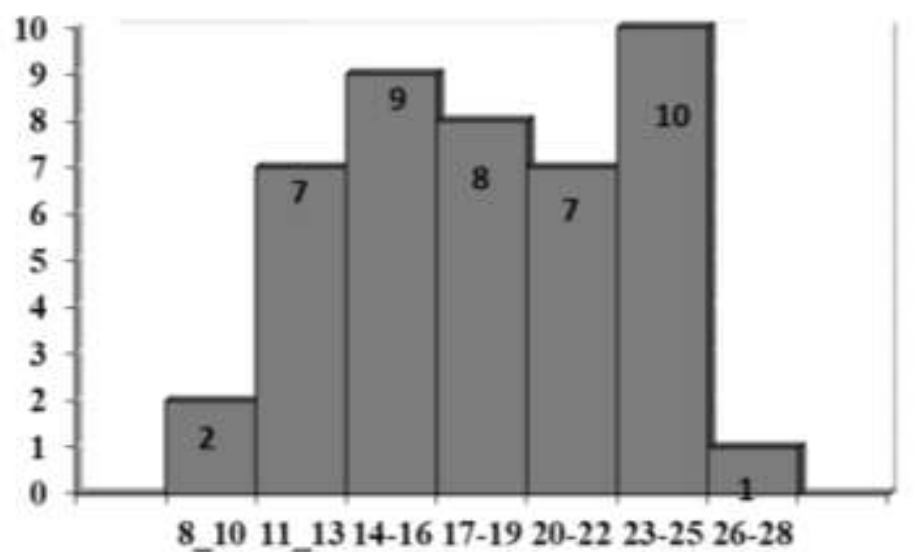

Figure 6. High and Low Motivation Histograms Taught by Using a Media-Aided Learning Model $\left(\mathrm{A}_{2}\right)$

While the evaluation categories of high and low Motivation data that are taught by using a learning model assisted by picture media can be seen in the following table: 
Vol. 2, No. 1, March 2020, Page: 494-507

Table 12. The High And Low Motivation Evaluation Categories of Teachers Taught By Using A Media-Assisted Learning Model $\left(\mathrm{A}_{2}\right)$

\begin{tabular}{|c|c|c|c|c|}
\hline No & Rating Interval & Total of Students & Percentage & Assessment Category \\
\hline 1 & $0 \leq$ MTMR $<45$ & 9 & $20 \%$ & Very Less \\
\hline 2 & $45 \leq$ MTMR $<65$ & 17 & $39 \%$ & Less \\
\hline 3 & $65 \leq$ MTMR $<75$ & 7 & $16 \%$ & Enough \\
\hline 4 & $75 \leq$ MTMR $<90$ & 11 & $25 \%$ & Well \\
\hline 5 & $90 \leq$ MTMR $\leq 100$ & 0 & $0 \%$ & Very Well \\
\hline & & 44 & $100 \%$ & \\
\hline
\end{tabular}

Note: MTMR = High Motivation Low motivation

Table 13. Data Frequency Distribution of High Motivation of Students Taught Using NHT Learning Models Assisted by Audiovisual Media and Pictures $\left(\mathrm{B}_{1}\right)$

\begin{tabular}{|c|c|c|c|}
\hline Class & Class Interval & Frequency & Cumulative Frequency (\%) \\
\hline 1 & $13-15$ & 7 & 15,91 \\
\hline 2 & $16-18$ & 8 & 18,18 \\
\hline 3 & $19-21$ & 15 & 34,09 \\
\hline 4 & $22-24$ & 6 & 13,64 \\
\hline 5 & $25-27$ & 7 & 15,91 \\
\hline 6 & $28-30$ & 1 & 2,27 \\
\hline & & & $\mathbf{1 0 0}$ \\
\hline \hline
\end{tabular}

Based on these values, a group data histogram can be formed as follows:

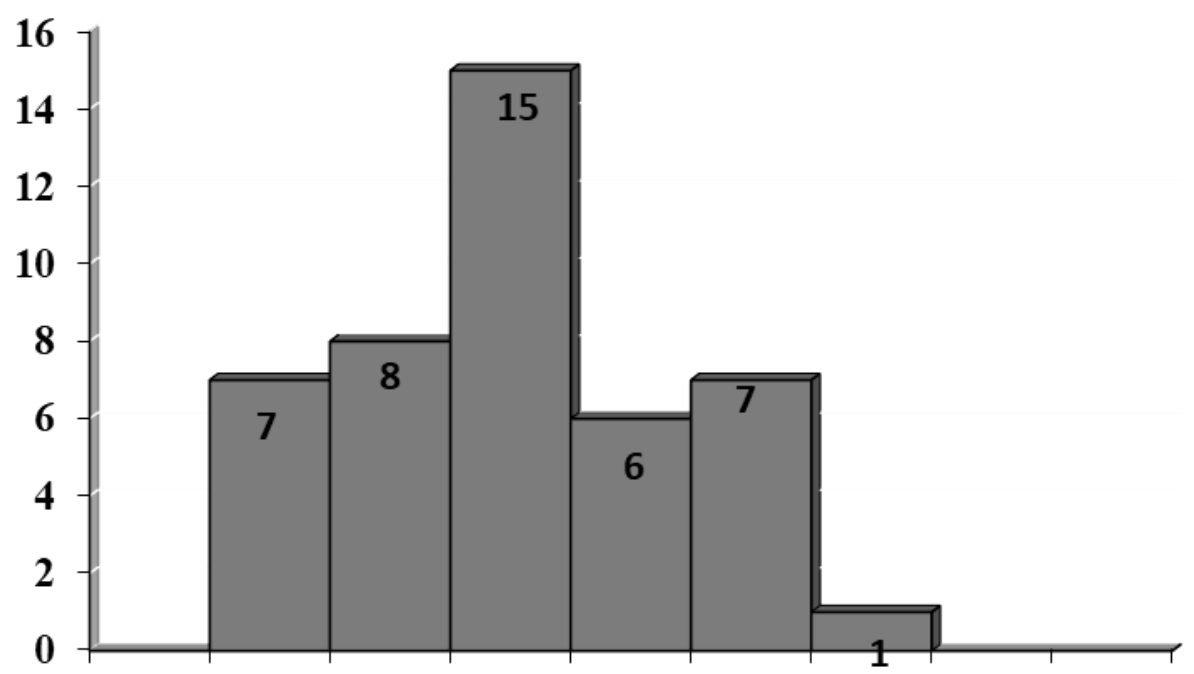

$\begin{array}{lllllll}13-15 & 16-18 & 19-21 & 22-24 & 25-27 & 28-30\end{array}$

Figure 7. High Motivation Histogram Taught Using the NHT Learning Model Assisted by Audiovisual Media and Pictures $\left(\mathrm{B}_{1}\right)$

While the category of evaluation of high motivation data taught using NHT learning models assisted by audiovisual media and pictures can be seen in the following table: 
Vol. 2, No. 1, March 2020, Page: 494-507

Table 14. High Motivation Assessment Categories are taught by using NHT learning models assisted by audiovisual media and images $\left(\mathrm{B}_{1}\right)$

\begin{tabular}{|c|c|c|c|c|}
\hline No & Rating Interval & Total of students & Percentage & Assessment category \\
\hline 1 & $0 \leq \mathrm{MT}<45$ & 2 & $5 \%$ & Very Less \\
\hline 2 & $45 \leq \mathrm{MT}<65$ & 18 & $41 \%$ & Less \\
\hline 3 & $65 \leq \mathrm{MT}<75$ & 13 & $30 \%$ & Enough \\
\hline 4 & $75 \leq \mathrm{MT}<90$ & 10 & $23 \%$ & Well \\
\hline 5 & $90 \leq \mathrm{MT} \leq 100$ & 1 & $2 \%$ & Very well \\
\hline & & 44 & $100 \%$ & \\
\hline
\end{tabular}

Table 15. Low Frequency Distribution of Student Motivation Data Taught Using the NHT Learning Model Assisted by Audiovisual Media and Pictures $\left(\mathrm{B}_{2}\right)$

\begin{tabular}{|c|c|c|c|}
\hline Class & Class Interval & Frequency & Cumulative Frequency (\%) \\
\hline 1 & $09 \_11$ & 5 & 11,36 \\
\hline 2 & $12 \_14$ & 10 & 22,73 \\
\hline 3 & $15-17$ & 10 & 22,73 \\
\hline 4 & $18-20$ & 11 & 25,00 \\
\hline 5 & $21-23$ & 3 & 6,82 \\
\hline 6 & $24-26$ & 5 & 11,36 \\
\hline \hline \multicolumn{2}{|c|}{ Total } & 44 & $\mathbf{1 0 0}$ \\
\hline
\end{tabular}

Based on these values, a group data histogram can be formed as follows:

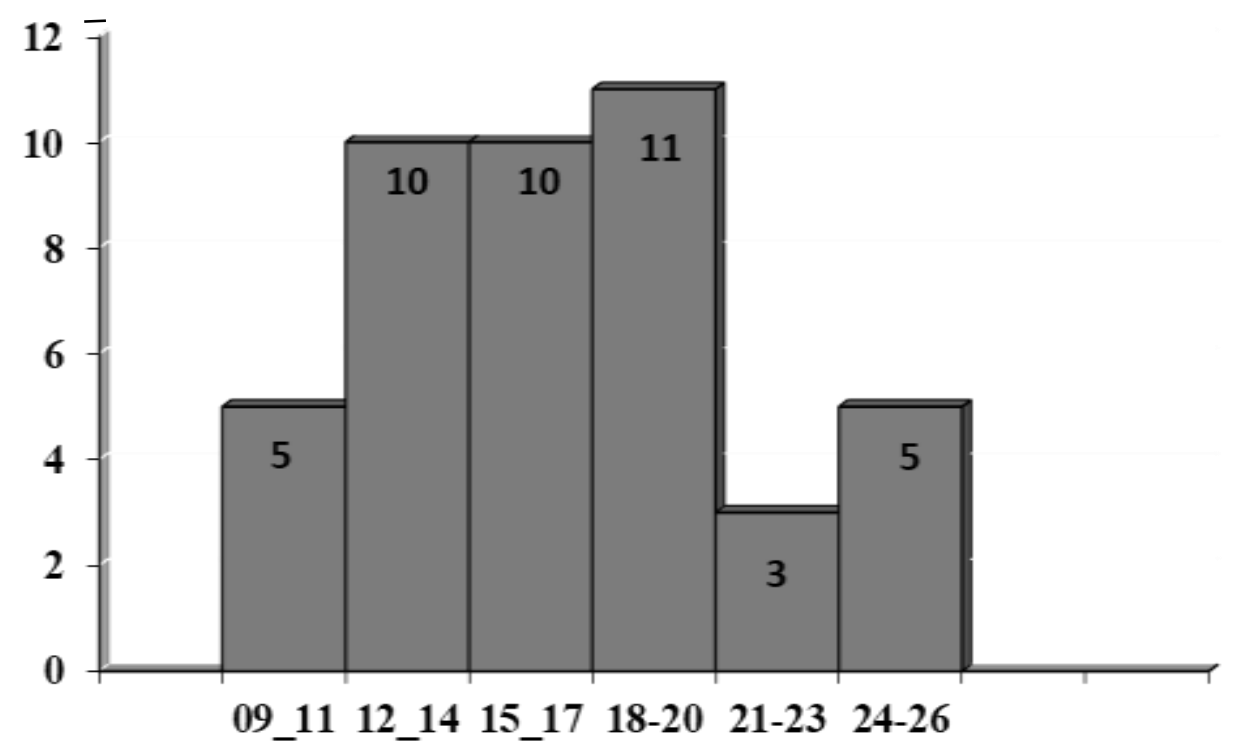

Figure 8. Histogram Motivation for Low Students Taught Using the NHT Learning Model Assisted by Audiovisual Media and Pictures $\left(\mathrm{B}_{2}\right)$

Whereas the category of assessment of low motivation data of students taught using NHT learning models assisted by audiovisual media and pictures can be seen in the following table: 
Vol. 2, No. 1, March 2020, Page: 494-507

Table 16. Low Student Motivation Assessment Categories Taught By Using NHT Learning Models Assisted by Audiovisual Media and Pictures $\left(\mathrm{B}_{2}\right)$

\begin{tabular}{|c|c|c|c|c|}
\hline No & Class Interval & Total students & Percentage & Assessment category \\
\hline 1 & $0 \leq \mathrm{MR}<45$ & 13 & $30 \%$ & Very less \\
\hline 2 & $45 \leq \mathrm{MR}<65$ & 20 & $45 \%$ & less \\
\hline 3 & $65 \leq \mathrm{MR}<75$ & 5 & $11 \%$ & Enough \\
\hline 4 & $75 \leq \mathrm{MR}<90$ & 6 & $14 \%$ & Well \\
\hline 5 & $90 \leq \mathrm{MR} \leq 100$ & 0 & $0 \%$ & Very Well \\
\hline & 44 & $100 \%$ & \\
\hline
\end{tabular}

Table 17. Results of Influence of High and Low Motivation of Students Taught by NHT Learning Models Assisted by Audiovisual Media and Pictures

\begin{tabular}{|c|c|c|c|}
\hline $\begin{array}{l}\text { Source of } \\
\text { Statistic }\end{array}$ & $\begin{array}{c}\mathrm{A}_{1} \text { (NHT } \\
\text { Audiovisual) }\end{array}$ & $\mathbf{A}_{2}$ (NHT Figure) & Total \\
\hline \multirow{6}{*}{$\begin{array}{l}\text { B }_{1}(\text { High } \\
\text { Motivation) }\end{array}$} & $\mathrm{n}=22$ & $\mathrm{n}=2$ & $n=44$ \\
\hline & $\sum X=511$ & $\sum X=417$ & $\sum X=928$ \\
\hline & $\sum X^{2}=12129$ & $\sum X^{2}=8341$ & $\sum X^{2}=20470$ \\
\hline & $\mathrm{Sd}=3,52$ & $\mathrm{Sd}=4,56$ & $\mathrm{Sd}=4,01$ \\
\hline & Var $=12,37$ & Var $=20,81$ & $\operatorname{Var}=16,12$ \\
\hline & Mean $=23,23$ & Mean $=18,95$ & Mean $=21,09$ \\
\hline \multirow{6}{*}{$\begin{array}{l}B_{2} \text { (Law } \\
\text { Motivation) }\end{array}$} & $\mathrm{n}=30$ & $\mathrm{n}=30$ & $\mathrm{n}=60$ \\
\hline & $\sum X=1544$ & $\sum X=1884$ & $\sum X=3428$ \\
\hline & $\sum X^{2}=82396$ & $\sum X^{2}=121558$ & $\sum X^{2}=203954$ \\
\hline & $\mathrm{Sd}=10,054$ & $S d=10,575$ & $\mathrm{Sd}=10,315$ \\
\hline & Var $=101,085$ & Var $=111,821$ & $\operatorname{Var}=106,453$ \\
\hline & Mean $=51,467$ & Mean $=62,800$ & Mean $=57,133$ \\
\hline \multirow{6}{*}{ Total } & $\mathrm{n}=44$ & $\mathrm{n}=44$ & $\mathrm{n}=88$ \\
\hline & $\sum X=894$ & $\sum X=794$ & $\sum X=1688$ \\
\hline & $\sum X^{2}=19188$ & $\sum X^{2}=15372$ & $\sum X^{2}=34560$ \\
\hline & $\mathrm{Sd}=4,88$ & $\mathrm{Sd}=4,93$ & $\mathrm{Sd}=4,53$ \\
\hline & Var $=23,80$ & Var $=24,28$ & Var $=20,49$ \\
\hline & Mean $=20,32$ & Mean $=18,05$ & Mean $=19,18$ \\
\hline
\end{tabular}

Note:

$A_{1}$ : Students taught by NHT Learning assisted by Audio-visual media

$A_{2}$ : Students taught by NHT Learning with media aids

$B_{1}$ : High motivation in students

$B_{2}$ : Low motivation in students

One of the analytical techniques in the normality test is the Lilliefors analysis technique, which is a requirement analysis analysis technique before conducting a hypothesis test. Based on a random sample, the null hypothesis is tested that the sample comes from a normally distributed population and a rival hypothesis that the population is not normally distributed. -calculate $<\mathrm{L}$ table then the data distribution has a normal distribution. But if L-count> L-table then the data 
distribution is not normally distributed. The results of the normality analysis for each sub-group can be explained as follows:

Based on the results of normality test calculations for samples on the results of high motivation students who were taught using NHT learning models assisted by audioviual media (A1B1) obtained L-count value $=0.146$ with $\mathrm{L}$-table value $=0.189$ Because the $\mathrm{L}$-count $<\mathrm{L}$-table ie $0.146<0.189$ then it can be concluded the null hypothesis is accepted. So it can be said that the motivation sample of students taught using NHT learning models assisted by audioviual media comes from a normally distributed population.

Based on the results of the calculation of normality test for samples on the results of high motivation of students taught using the NHT learning model assisted by picture media (A2B1), the $\mathrm{L}$-count value $=0.079$ with the $\mathrm{L}$-table value $=0.189$. Because the $\mathrm{L}$-count $<\mathrm{L}$-table is 0.079 $<0.189$, it can be concluded that the null hypothesis is accepted. So that it can be said that the sample on the results of high motivation of students taught by using the NHT learning model assisted by the image media comes from a normally distributed population.

Based on the results of normality test calculations for samples on the results of low motivation of students who were taught using NHT learning models assisted by audiovisual media (A1B2) obtained L-count $=0.083$ with $\mathrm{L}$-table value $=0.189$. Because $\mathrm{L}$-count $<\mathrm{L}$-table, it can be concluded that the null hypothesis is accepted. So it can be said that the sample on the low motivation results of students taught using NHT learning models assisted by audiovisual media comes from a normally distributed population.

Based on the results of the calculation of normality test for samples on the results of low motivation of students who were taught using the NHT learning model assisted by picture media (A2B2), the L-count value $=0.113$ with the $\mathrm{L}$-table value $=0.189$. Because the $\mathrm{L}$-count $<\mathrm{L}$-table is $0.113<0.189$, it can be concluded that the null hypothesis is accepted. So it can be said that the sample on the low motivation results of students taught by using the NHT learning model assisted by picture media comes from populations that are normally distributed.

Based on the results of normality test calculations for samples on the results of high and low motivation of students taught using NHT learning models assisted by audiovisual media (A1) obtained L-count value $=0.057$ with L-table value $=0.133$. Because the $\mathrm{L}$-count $<\mathrm{L}$-table is $0.057<0.133$, it can be concluded that the null hypothesis is accepted. So it can be said that the sample on the results of high and low motivation of students taught using NHT learning models assisted by audiovisual media comes from populations that are normally distributed.

Based on the results of the calculation of normality tests for samples on the results of high and low motivation of students who were taught using the NHT learning model assisted by the media image (A2) obtained $\mathrm{L}$-count value $=0.095$ with $\mathrm{L}$-table value $=0.133$. Because the Lcount $<$ L-table is $0.095<0.133$, it can be concluded that the null hypothesis is accepted. So it can be said that the sample on the results of high and low motivation of students taught using NHT learning models assisted by audiovisual media comes from populations that are normally distributed. 
Vol. 2, No. 1, March 2020, Page: 494-507

Table 18. Summary of Normality Test Results with Lilliefors Analysis Techniques

\begin{tabular}{|c|c|c|l|}
\hline Group & L-Counting & L - table $\boldsymbol{\alpha}=\mathbf{0 , 0 5}$ & \multicolumn{1}{|c|}{ Conclusion } \\
\hline $\mathrm{A}_{1} \mathrm{~B}_{1}$ & 0,146 & \multirow{4}{*}{0,189} & Ho: Accepted, Normal \\
\hline $\mathrm{A}_{1} \mathrm{~B}_{2}$ & 0,083 & & Ho: Accepted, Normal \\
$\mathrm{A}_{2} \mathrm{~B}_{1}$ & 0,079 & & Ho: Accepted, Normal \\
\hline $\mathrm{A}_{2} \mathrm{~B}_{2}$ & 0,113 & & Ho: Accepted, Normal \\
\hline $\mathrm{A}_{1}$ & 0,057 & \multirow{4}{*}{0,133} & Ho: Accepted, Normal \\
\hline $\mathrm{A}_{2}$ & 0,095 & & Ho: Accepted, Normal \\
\hline $\mathrm{B}_{1}$ & 0,081 & & Ho: Accepted, Normal \\
\hline $\mathrm{B}_{2}$ & 0,095 & & Ho: Accepted, Normal \\
\hline
\end{tabular}

Information:

- $\quad$ A1B1 $=$ High Student Motivation Results Teased by Using NHT Learning Models Assisted by Audiovisual Media

- A1B2 = Low Motivation Results of Students Taught by Using NHT Learning Models Assisted by Audiovisual Media

- $\quad$ A2B1 = High Student Motivation Results Teased by Using the NHT Learning Model aided by image media

- $\quad$ A2B2 = Low Motivation Results of Students Taught by Using the NHT Learning Model aided by image media

Homogeneity testing of population variance that is normally distributed is done by the Bartlett test. From the calculation results $\square 2$ arithmetic (chi-squared) obtained value is smaller than the price on the $\square 2$ table. The statistical hypothesis tested is stated as follows:

$\mathrm{H} 0$ :

Ha: at least one sign is invalid

With the Provisions If X 2 count $<\mathrm{X} 2$ table then it can be said that, the respondent used as a research sample does not differ or resemble the characteristics of the population or homogeneous. If X2 count $>\mathrm{X} 2$ table then it can be said that, the respondents used as research samples differ in characteristics from the population or are not homogeneous.

\section{Conclusion}

Validation of experts on teaching materials to write short story text based on character education based on the results of this study shows: Material expert validation on content eligibility assessment is in very valid criteria with an average value of $85 \%$. Feasibility of presentation is very valid criteria with an average value of $90 \%$, and language eligibility is very valid criteria with an average value of $87 \%$. The validation of the design expert on the evaluation of teaching material validation of short story text based on character education in the aspect of graphic with very valid criteria with an average value of $88.6 \%$. The results of the questionnaire responses / responses of teachers to teaching materials to write short story text based on character education with an average value of $80 \%$ in the category of practical / good. The results of the questionnaire responses of students by $90 \%$ with the category of very good / very practical. 


\section{References}

Akbar, S. 2010. Model Pembelajaran Nilai dan Karakter Berbasis Nilai-nilai Kehidupan di Sekolah Dasar. Jurnal Ilmu Pendidikan, (Online), 17 (1):46-54, (http://journal.um.ac.id/index/jip/article/viewFile/2619/1349, diakses 25 Maret 2017).

Andrianto, Tuhana Tufiq. 2011. Mengembangkan Karakter Sukses Anak di Era Cyber. Yogyakarta: Ar-Ruzz Media.

Anwar, Ilham. 2010. Pengembangan Bahan Ajar. Bahan Kuliah Online. Direktori UPI. Bandung. Ashyar, Rayandra.2012. Kreatif Mengembangkan Media Pembelajaran . Jakarta : Referensi Jakarta.

Asriani, Piti. dkk. 2017. Bahan Ajar Berbasis Pendidikan Karakter untuk Siswa Kelas IV Sekolab Dasar. Jurnal Pendidikan: Teori dan Pengembangan Volume 2 Nomor 11 November 2017. Universitas Negeri Malang.

Barnawi \& Arifin. 2012. Strategi \& Kebijakan Pembelajaran Pendidikan Karakter. Yogyakarta: Ar-Ruzz Media.

Borg, Walter. R., and Gall. Meredith D. 1983. Educational Research an Introduction New York and London, Longman Inc.

Daryanto. 2013. Menyusun Modul : Bahan Ajar untuk Persiapan Guru dalam Mengajar. Yogyakarta : Gavamedia.

Depdiknas.2002. Teknik Belajar dengan Modul. Jakarta : Dirjen Pendidikan dasar dan Menengah.

Depdiknas. 2003. Undang-Undang No. 20 tahun 2003, Sistem Pendidikan Nasional, www.depdiknas.go.id.

Depdiknas. 2003. Kamus Besar Bahasa Indonesia Edisi Ketiga . Jakarta : Balai Pustaka.

Depdiknas. 2008. Pengembangan Buku teks pelajaran [Online]. Tesedia: http://www.scribd.com/doc/5702869/11-Pengembangan-Bahan-Ajar [18 Agustus 2014].

Diponegoro, M. 2011. Nulis Cerpen Yuk! Jakarta : Narasi.

Direktorat Pembinaan SMA Ditjen Pendidikan Dasar dan Menengah. 2017. Modul Penyusunan Soal-Soal HOTS. Jakarta.

Gunawan, H. 2012. Pendidikan Karakter: Konsep dan Implementasi. Bandung: Alfabeta.

Hamdani. 2010. Strategi Belajar Mengajar: Bandung: Pustaka Setia.

Haryanto, 2017. Nilai - Nilai yang Penting Terkait dengan Etika. Jurnal Psikologi Ulayat, Vol. 4 No. 1/Juni 2017.

Herfanda, A.Y. 2008. "Sastra sebagai Agen Perubahan Budaya" dalam Bahasa dan Budaya dalam Berbagai Perspektif, Aanwar Effendi, ed. Yogyakarta: FBS UNY dan Tiara Wacana.

Kosasih, E. Apresiasi Sastra Indonesia. Jakarta : Nobel Edumedia

Kesuma, D., Cepi Triatna., \& Johar Permana. 2012. Pendidikan Karakter: Kajian Teori dan Praktik di Sekolah. Bandung: PT Remaja Rosdakarya.

Prastowo, Andi. 2015. Panduan Kreatif Membuat Bahan Ajar Inovatif. Jogjakarta : Diva Press.

Priyatni, Endah Tri. 2010. Membaca Sastra dengan Ancangan Literasi Kritis. Jakarta : Bumi Aksara

Putra, N. 2012. Research and Development Penelitian dan Pengembangan : Suatu Pengantar. Jakarta : Rajawali Press.

Richey, Rita C., and Klein, James D. 2007. Design Development and Research Methods, Strategies, and Issues. London. Lawrence Erlbaum Associates Publishers.

Ridwan, Muhamad. 2012. Menyemai Benih Karakter Anak. dari http://www. adzzikro.com

Russel D, James. 1997. Teknologi Pembelajaran dan Media untuk Belajar.

Salahudin, A. \& Irwanto Alkrienciehie. 2013. Pendidikan Karakter Berbasis Pendidikan Agama dan Budaya Bangsa. Bandung: CV Pustaka Setia

Sani, Ridwan Abdullah. 2014. Inovasi Pembelajaran . Jakarta : Bumi Aksara.

Sayuti, S. A. dkk. 2009. Modul Menulis Fiksi. Yogyakarta : PBSI FBS UNY.

Siswanto, Wahyudi. 2008. Pengantar Teori Sastra. Jakarta : Grasindo. 
Soenarto. 1983. Metodologi Pengembangan untuk Peningkatan Kualitas Pembelajaran. Makalah disampaikan pada Pelatihan Nasional Penelitian Peningkatan Kualitas Pembelajaran dan Penelitian Tindakan Kelas bagi dosen LPTK di Padang dan Mataram 5-9 April 2006.

Sugiyono. 2011. Metode Penelitian Kombinasi (Mixed Methods). Bandung : Alfabeta.

Sugiyono. 2015. Metode Penelitian Kuantitatif Kualitatif dan R \& D. Bandung: Alfabeta.

Sugiyono. 2016. Metode Penelitian Kuantitatif, kualitatif, dan R \& D. Bandung : Alfabeta.

Suherly, dkk. Bahasa Indonesia SMA Kelas XI. Jakarta : Kemendikbud.

Suyadi. 2012. Buku Panduan Guru Profesional - Penelitian Tindakan Kelas (PTK) dan Penelitian Tindakan Sekolah (PTS) Yogyakarta : Andi.

Tegeh, Made dkk. 2014. Model Penelitian Pengembangan. Yogyakarta: Graha Ilmu.

Wibowo, A. 2013. Manajemen Pendidikan Karakter di Sekolah. Yogyakarta: Pustaka Pelajar.

Winkel. 2009. Psikologi Pengajaran. Yogyakarta : Media Abadi. 